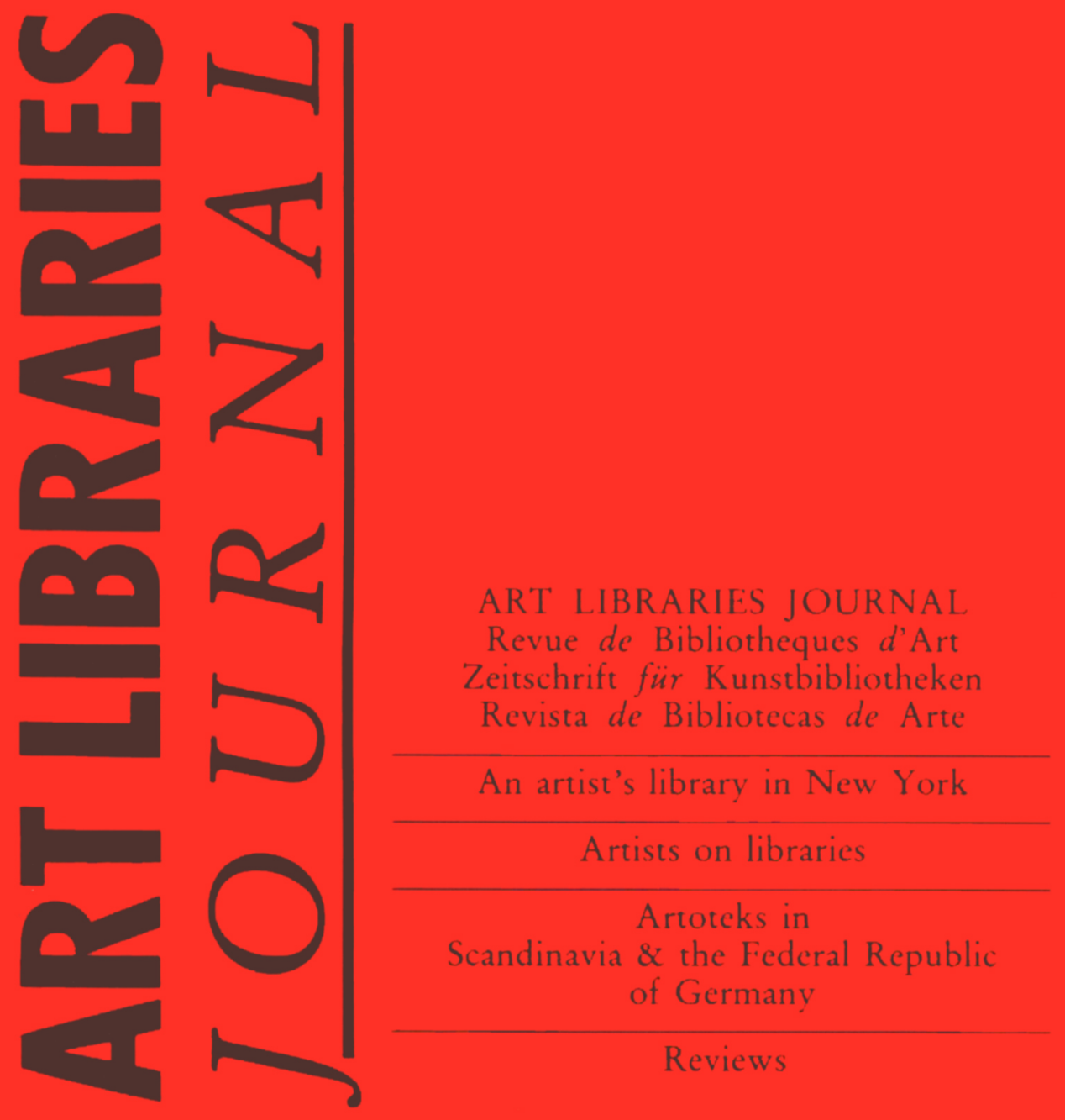

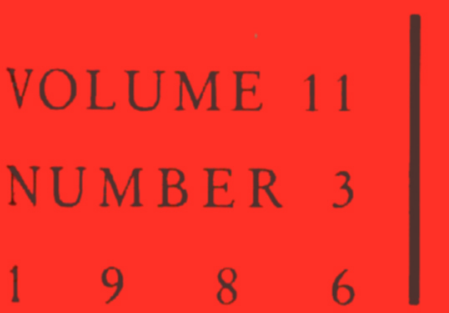




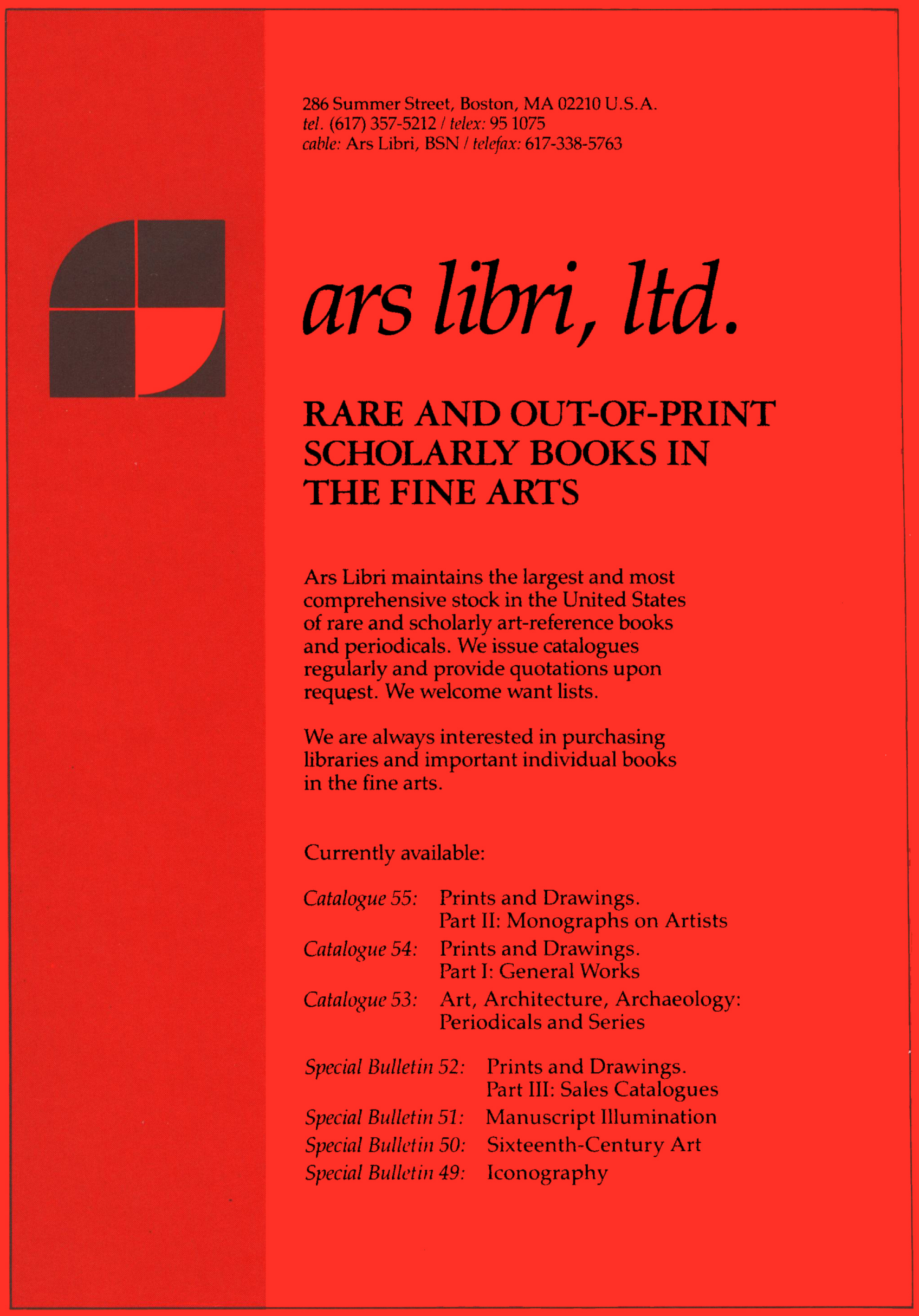




\section{SLIDES OF PRINTS}

Selected from the Department of Prints \& Drawings in the British Museum.

\section{Der Ackermar.}

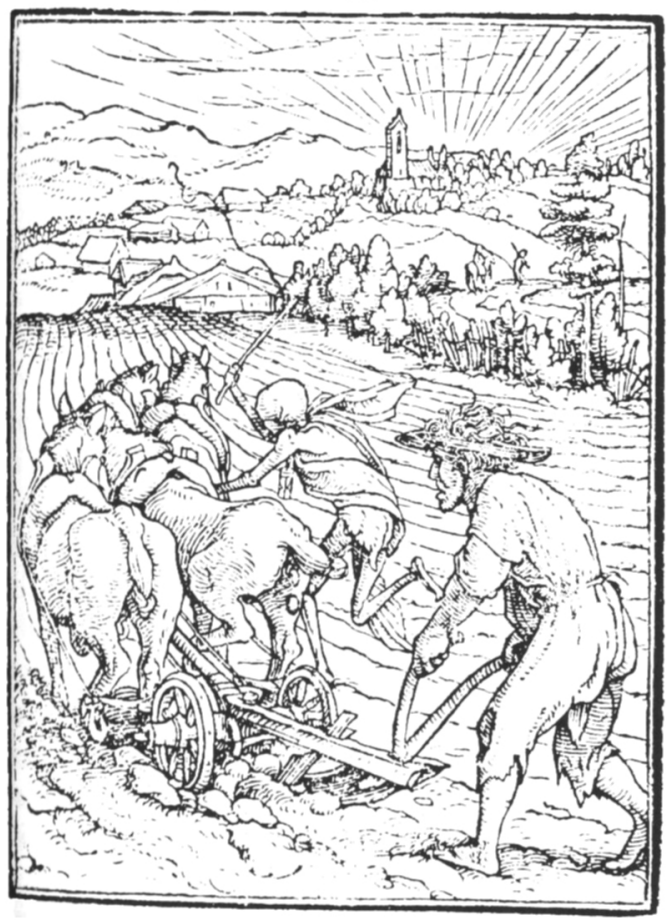

Holbein, The Ploughman

From the Dance of Death, 1522-25

Woodcut Enlarged

The British Museum has generously allowed a large number of prints in the Department of Prints and Drawings to be photographed for educational purposes.

As a consequence of working directly from the finest originals, the slides display the technique, style and quality of each print with exceptional clarity.

The complete series numbers over 1200 slides, including details. Sets and slides of single prints may also be ordered.

For a full catalogue write or phone to:

\section{ICARUS,}

Slides for Teaching the History of Art, 158 Boundaries Road

London SW12 8HG.

Tel: $01-4160900$.
ART LIBRARIES JOURNAL Revue de Bibliotheques d'Art Zeitschrift für Kunstbibliotheken Revista de Bibliotecas de Arte

VOLUME 11 NUMBER 31986

EDITOR PHILIP PACEY

3

Editorial

5

Red is for Painting: the SoHo Center Library

Sharon Chickanzeff

9

Artists on Libraries 1: Tom Phillips

11

Artists on Libraries 2 .

Peter Trepanier

13

Artists on Libraries 3 :

Ornulf Opdabl

14

Avigdor Arikha

16

Art Libraries in Denmark Benedicte Bojesen

20

The Norwegian Artoteksentralen

(The Artotheque Centre) -

co-operation between artists and library authorities Anders Ericson

22

Artotheque activities in Swedish public libraries

Sven-Olaf Svensson

27

An art lending service in Finland Ilmi Järvelin

31

10 Jahre Graphotek in der Stadbibliothek Bremen

Gerd-Peter Patz

35

Reviews

Alex Ross, Jack Perry Brown, Anthony J. Coulson

ISSN 03074722

(C) ARLIS/UK \& EIRE
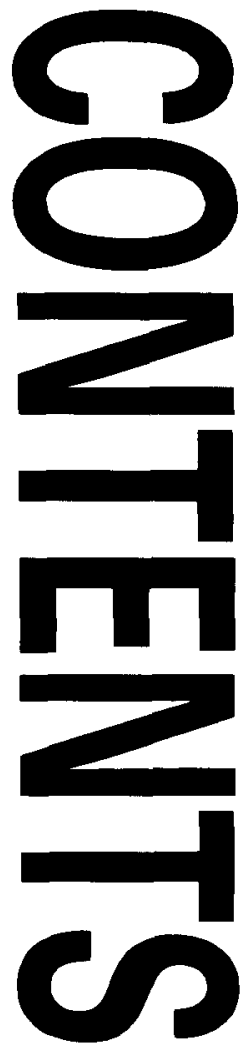
ART LIBRARIES JOURNAL

Revue de Bibliotheques d'Art

Zeitschrift für Kunstbibliotheken

Revista de Bibliotecas de Arte

Editor: Philip Pacey,

Lancashire Polytechnic Library,

St. Peter's Square,

Preston PR1 2TQ, U.K.

Deputy Editor: Mary Ashe, Art and Music Department, San Francisco Public Library,

Civic Center,

San Francisco,

California 94102, U.S.A.

Reviews Editor (North America):

Alexander D. Ross,

Art and Architecture Library,

Stanford University,

102 Cummings Arts Building,

Stanford,

California 94305, U.S.A.

\section{Advertising Manager:}

Douglas Dodds,

Coventry Polytechnic

Art and Design Library,

Gosford Street,

Coventry CV1 5RZ, U.K.

Circulation Manager:

Pat Christie,

Epsom School of Art Library,

Ashley Road,

Epsom,

Surrey KT18 5VE, U.K.
The Art Libraries Journal is an international forum for art librarians and for all those whose interests include art librarianship, art libraries, art departments and art collections within libraries, and art documentation of all kinds including visual resources. The contents of the Art Libraries Journal regularly include conference papers of the IFLA Section of Art Libraries.

The Art Libraries Journal publishes material in English, French, German, and Spanish; articles in languages other than English will normally be accompanied by an English summary.

In addition to articles and conference papers, the Art Libraries Journal publishes reviews of books about, or relevant to, art librarianship, and of bibliographies and major reference works within the broad area of the visual arts. A regular column contributed by the IFLA Section of Art Libraries provides current awareness of art bibliographies. Letters from readers are always welcome as a means of continuing and developing discussion of issues raised in these pages.

Contributions are warmly invited, and should be submitted to the Editor; books for review may be sent to the Editor or to the Reviews Editor (North America).

The Art Libraries Journal is published quarterly, and normally appears in March, May, September and January. It is published by ARLIS/UK and Eire for the art library profession worldwide; readers' views, comments, and suggestions are sought and valued, and should be directed to the Editor.
The Art Libraries Journal is distributed to members of ARLIS/UK and Eire (including Overseas members) as part of their membership, and is available to subscribers outside the U.K. @ $£ 29.00$ per annum, postage included.

For details of U.K. membership apply to:

Linda Newington,

Camberwell School of Art Library,

Peckham Road,

London SE5 8UF, U.K.

For details of overseas membership or to subscribe to the

Art Libraries Journal, apply to:

Liz White,

Trent Polytechnic Library,

School of Art and Design,

Dryden Street,

Nottingham NG1 4FZ, U.K.

Single copies may be purchased at $£ 6.40$ ( $£ 5.50$ to ARLIS/UK

and Eire members), postage inc.

from:

Pat Christie

Epsom School of Art Library,

Ashley Road,

Epsom,

Surrey KT18 5VE, U.K.

Subscription copies not received should be claimed from the Circulation Manager. Claims will be accepted until two years after publication. 